\title{
sciendo
}

\section{Social Responsibility and Loyalty in Public Relations Codes}

\author{
Matilda Kolić Stanić \\ University of Zagreb, University Department of Croatian Studies, Zagreb, \\ Croatia \\ Anton Florijan Barišić \\ University of Applied Sciences VERN, Zagreb, Croatia
}

\section{Abstract}

Background: It is believed that social responsibility, the value that is strongly involved in the contemporary corporate behaviour, has also become the core value for public relations practitioners and their associations. However, there are ethical doubts concerning the question to whom a PR practitioner is actually responsible (or loyal) in the first place: to the client, the employer, the public, or society in general? Objectives: This research aims to describe how social responsibility is articulated in the documents that can be considered as the crown of public relations ethics - the codes of ethics and additionally, how the value of loyalty corresponds to the value of social responsibility. Methods/Approach: The research is based on the content analyses of 13 codes of ethics that are delivered by 18 public relations associations at the international and the national level in the USA and the European Union. Results: Although the phrase "social responsibility" is not mentioned in codes directly, the value of social responsibility is present in very diverse ways. When the value of loyalty came into the correlation with social responsibility, the research has shown that these values exist as a separate principle. Conclusions: The public relations are a profession that tends to be socially responsible and tends to show that loyalty to clients and organizations is subordinated to public and social responsibility. Thus, the codes show that contemporary public relations, at least at the normative level, approach the twoway symmetric model and mostly promote "idealistic social role" of public relations.

Keywords: public relations, ethics, social responsibility, loyalty, ethic codes

JEL classification: M14, D8

Paper type: Research article

Received: Sep 1, 2018

Accepted: Jul 28, 2019

Citation: Kolić Stanić, M., Barišić, A. F. (2019), "Social Responsibility and Loyalty in Public Relations Codes", Business Systems Research, Vol. 10, No. 2, pp. 151-162.

DOI: 10.2478/bsrj-2019-024

\section{Introduction}

Can anyone be responsible and not being loyal? Can someone be loyal and not being responsible? If these ethical issues are tearing, or expanding, to social responsibility and loyalty in business, whether among corporations or non-profit sectors, and considering that these issues are nowadays inseparable from the public relations sector who communicates them to public (e.g., Kim and Reber, 2009; Pejić 
Bach, et al. 2015; Barić, 2017), these are no longer ethical topics that could be discussed just at a grass-roots level. They are rather "top-topics" for both public relations and business, among scholars and practitioners. This research dominantly approaches to the question of social responsibility from the perspective of public relations and seeks to find how the principle of social responsibility and loyalty affects public relations.

James Grunig articulated the role of public relations professionals by stating that they are serving "as ethical counsellors to organizations, a role in which they help organizations behave in ethical, responsible, and sustainable ways" (Grunig, 2014). The main question of this research is how do the ethics of public relations professionals look like regarding social responsibility and loyalty as the values presented in their codes of ethics. The answer to that question can be considered as a contribution to the call of Grunig who asked to deal with the ethical principles in public relations since the discussions about ethics and social responsibility in the public relations literature were ignoring ethical theory or principles $(2014,15)$. Ethics has become the crucial issue in building relationships for both, organizations and public relations (Bowen et al., 2016; Stoker, 2005), and furthermore, ethics of PR professionals is especially important in the context of corporate social responsibility (Farmer, 2018).

There is no doubt that public relations have an important social role, which invokes ethical behaviour of its practitioners (e. g., Yang and Taylor, 2013; Kolić Stanić, 2019), especially in establishing connections among organizations and public, what can also have positive environmental effects (Yang et al., 2016).

The goal of the paper is to present how the documents that could be considered as the "ethical crown" of public relations as a "socially responsible profession" - the ethics codes of the public relations associations - refer to the value of social responsibility. Considering that recent academic discussions link the value of social responsibility to the value of loyalty, the goal is also to compare those two values and to show how they build ethical public relations.

The content of the paper is as follows. After the introduction, we focus on a literature review on values of social responsibility and loyalty in general, especially in the context of ethics in public relations. The methodological part of the paper explains how the content analyses were provided on the codes of ethics to bring the results, which are grouped into three parts - social responsibility, loyalty, and their mutual relation. After the discussion, the paper in the conclusions also brings some proposals for PR-ethics.

\section{Literature review}

\section{Loyalty matters}

There exist some serious difficulties in PR-professionals everyday work which are dealing with, so to say, the biblical wisdom which says that no one can serve two masters. Those two masters in the case of public relations practitioners can be grouped in society's/stakeholders'/public's interests and organizations'/clients' interests (Jackson and Moloney, 2019; Farmer, 2018), whereby public relations come in the situation of "dual-responsibility" (Taylor and Yang, 2015, p. 553). That is, actually, bringing the ethical issue to the great topic of loyalty in public relations. Many words on loyalty can be replaced by the sentence written by Grunig, who has broken the "stereotype" that the professionals can be loyal or to the client, or to the organization:

"Perhaps the most important question that I have addressed theoretically in my 50 years as a public relations theorist is whether public relations should be practiced asymmetrically or symmetrically-in the interest only of a client organization or in the interests of publics, stakeholders, and society as well as the organization" $(2014,21)$ 
Grunig, based on White's division (Grunig and White, 1992), confronts 4 types of PRpractitioners to their pragmatic, conservative, radical, and idealistic social roles. He concludes that "the idealistic social role" belongs to the practitioner who believes that "public relations serve the interests of publics as well as organizational interests, contributes to informed debate about issues in society, and facilitates a dialogue between organizations and their publics" (Grunig, 2014, 26). That view is so opposite to the attitude of PR-professionals' "exclusive loyalty to a client", which can harm other members of society (Jackson and Moloney, 2019). Stoker (2005) is directly linking loyalty and social responsibility, which can both be established within professionals in public relations. But is this connection also present in codes of ethics of public relations, which are the meeting point of the collected norms and good practices of professionals (Yang et al., 2016)? Although there are very significant researches which analysed codes of ethics of public relations associations, the correlation between social responsibility and loyalty in codes was not articulated in a direct way. Analysing social responsibility and loyalty in codes makes sense, especially if one takes into account that the codes of ethics treat the role of public relations professionals in organization and in society (Yang et al., 2015). On the other hand, the codes of ethics can be considered as a complex product of engagement of both, professionals and academics, which is the part of the strategy for public relations associations (Kolic Stanić, 2018c).

This research tries to answer to three research questions: How are in codes of ethics in public relations represented the value of social responsibility (1) and the principle of loyalty (2), and what is the correlation between them (3)?

\section{Social responsibility}

In the majority of previous studies, social responsibility (SR) or either corporate social responsibility (CSR) has been predominantly considered as an organization's management perspective (Vlachos et al., 2009; Du, Bhattacharya and Sen, 2010). Recently, SR implementation is based on two drivers; one is considering organizations as a powerful and positive force for social change, while another relies on SR efforts as a potential multi-faceted business return (Pompper, 2015).

Using the World Bank definition of CSR, Preciado-Hoyos (2013) claims that social responsibility is "the commitment of organization to contribute to sustainable economic development working with employees, their families, the local community, and society to improve their quality of life, in ways that are both good for business and good for development", while Daymon and Holloway, (2010), define SR as "a commitment to improving societal well-being through discretionary business practices and contributions of corporate resources". Many similar definitions conceptualize SR in terms of the economic, legal, ethical, and philanthropic dimensions (Vlachos et al., 2009; Chen, Chang and Lin, 2012).

Numbers of studies testify that SR as a substantial managerial and administrative apparatus enabling organizations to participate in social activities, provides a prospective directly related to financial performance, brand performance, client satisfaction, and organizations political activities (Pompper, 2015; Du, Bhattacharya and Sen, 2010; May 2008).

Recently there are a number of studies dedicated to the recognition of the relationship between SR and evaluation of PR professional estimate and perception (Jones and Bartlett, 2009), is focused more on the client's perspective rather than the organizational perspective of SR (Wright, 1979; Boynton, 2002). Thus, professional perspective embodies the relationship between value relevance and ethical standards as a determining factor in SR engagement and client loyalty (Chen, Chang, 
and Lin, 2012; Grunig, 2006). Thereby, ethical standards include the fair, rightful and correct performance of organization's activities clearly indicated in the organization's code of conduct and communicated as the organizational commitment to SR endeavours (Kim and Park, 2011; Kim and Reber, 2008).

Some other typologies distinguish other SR dimensions such as community support, diversity, employee support, environment, international operations, and services, (Kim and Reber, 2008), or dimensions such as respect for the environment, respect for clients, respect for employees and implemented philanthropic activities (Boynton, 2002).

Social responsibility at both, corporative sector (as well as among other types of organizations) and public relations departments and its practitioners, are tightly connected, although sometimes the leaders of corporations do not share the awareness that PR is not just department for making positive publicity (Benn, Todd, and Pendelton, 2010). PR'S rather should be considered as professionals, an expert in communication, engaged in the strategical building of social responsibility (Clark, 2000; Fitzpatrick and Gauthier, 2001).

\section{Methodology}

The sample of the research included 13 codes: 2 codes of ethics from international associations (Global Protocol on Ethics in Public Relations - GA Code and The ICCO Stockholm Charter - ICCO Code) and 11 national codes among EU member states and the United States of America.

Table 1

The Sample of the Research

\begin{tabular}{|c|c|c|}
\hline Country & Code & Code's Full Name \\
\hline Austria & PRVA Code & $\begin{array}{l}\text { Code of Conduct of the Austrian Public Relations } \\
\text { Association }\end{array}$ \\
\hline Croatia & CPRA Code & Croatian Public Relations Association Code of Ethics \\
\hline Germany & DRPR Code & The German Communication Code \\
\hline Italy & FERPI Code & $\begin{array}{l}\text { Italian Public Relations Federation Code of Professional } \\
\text { Conduct }\end{array}$ \\
\hline Italy & Assorel Code & $\begin{array}{l}\text { Professional Principles and Codes of Conduct for Public } \\
\text { Relations in Italy }\end{array}$ \\
\hline UK & PRCA Code & PRCA Professional Charter \\
\hline UK & CIPR Code & Chartered Institute of Public Relations Code of Conduct \\
\hline Spain & Dircom Code & Association of Communication Managers Code of Ethics \\
\hline Spain & ADECEC Code & $\begin{array}{l}\text { Association of Communication and Public Relations } \\
\text { Consultancy Companies Code of Ethics }\end{array}$ \\
\hline USA & PRSA Code & PRSA Code of Ethics \\
\hline USA & PR Council Code & The PR Council Code of Ethics and Principles \\
\hline Interr & GA Code & Global Protocol on Ethics in Public Relations \\
\hline International & ICCO Code & The ICCO Stockholm Charter \\
\hline
\end{tabular}

Source: Authors' work

From the following countries, the research took one code of ethics which relates to one association: Austria (PRVA Code - Code of Conduct of the Austrian Public Relations Association), Croatia (CPRA Code - Croatian Public Relations Association Code of Ethics), Germany (DRPR Code - The German Communication Code). Since some of the countries have PR-association that distinguish type of its membership (individual or corporative, from the following countries the research, took 2 codes of ethics: Italy (FERPI Code - Italian Public Relations Federation's Code of Professional 
Conduct and Professional Principles and Codes of Conduct for Public Relations in Italy - Assorel Code); Spain (Association of Communication Managers Code of Ethics Dircom Code and Association of Communication and Public Relations Consultancy Companies Code of Ethics - ADECEC Code); United Kingdom (PRCA Professional Charter - PRCA Code and Chartered Institute of Public Relations Code of Conduct CIPR Code); USA (PRSA Code of Ethics - PRSA Code and The PR Council Code of Ethics and Principles - PR Council Code) (Table 1).

For the purpose of the research a matrix was created (Kolić Stanić, 2018a) focusing to two key concepts - social responsibility and loyalty, and each of these terms came into several sub-terms, which will be shown in the Results section.

Using content analyses (Krippendorff, 1980) the codes of ethics were analysed with respect to include as many meaning as possible within these two central terms, and since the codes were analysed in the original languages in which they were written (German, Croatian, English, Italian and Spanish), the aim was to avoid that any lingual differences discriminate the results. All analysed codes were downloaded from the association's websites, translated into English if they have not already published the code in English. The versions of codes released after November 2017 have not been taken into consideration since the aim was to make a fair comparison.

\section{Results}

In this study, the first research question was to describe how is the value of social responsibility represented in the codes of ethics. Due the fact that the research of 13 national and international codes of ethics did not find the phrase "social responsibility" in any of analysed codes - although the scholars and practitioners regularly use that term in explaining the function of public relations - the second step was to find which terms connected to the concept of social responsibility (Kolić Stanić, 2018a) are present in the sample.

As pointed above, the research did not find the phrase "social responsibility" nor as a term, neither as section (the closest is FERPI with a section "Obligations towards public opinion and the media"; or PRCA with "Conduct towards the Public, the Media, and other Professionals"; or ICCO just with "Society"). However, the elements of the concept of social responsibility are present in codes, which, for the purpose of this paper was divided into 3 sections. First two sections - public in general and society were especially focused on the "interests" for both of them. The third section was dealing with the term responsibility since that term is the crucial part of the social responsibility as a value (Table 2 ).

Table 2

Elements of the Concept of Social Responsibility in the Codes of Ethic

\begin{tabular}{lllll}
\hline Public in general & Society & Responsibility & $\begin{array}{l}\text { Public } \\
\text { interest }\end{array}$ & $\begin{array}{l}\text { Society's } \\
\text { interest }\end{array}$ \\
\hline CPRA & PRVA & CPRA & CPRA & ADECEC \\
FERPI & CPRA & DRPR & FERPI & PRSA \\
PRCA & DRPR & PRCA & PRCA & GA \\
CIPR & ASSOREL & DIRCOM & PRSA & \\
ADECEC & DIRCOM & PRSA & PRCOUNCIL & \\
PRSA & ADECEC & GA & & \\
PRCOUNCIL & PRSA & ICCO & & \\
GA & PRCOUNCIL & & & \\
& GA & & & \\
& ICCO & & & \\
\hline
\end{tabular}

Source: Authors' work 


\section{Social responsibility and public in general}

Public relations, as expected, also in the context of its social responsibilities are the most of the time dealing with the publics, so it is not strange that the most present terms are linked to publics. But in the concept of social responsibility, aiming to put close to each other the terms public and society, in this study we are focusing on the public in general.

According to codes, the clear duty for PR-professionals is to always behave correctly, fairly, and honestly with the public. The obligation is to provide fair and impeccable treatment with the public in general and to assure the public the highest level of professionalism and ethical conduct. Furthermore, PR-practitioners must be guided by a higher sense of serving the public as a whole and to uphold the public trust at all times. The concept of social responsibility is especially articulated according to "public interests" by stating that practitioners should take into account and serve the public good, to respect and to be honest and responsible towards public interests. Furthermore, the obligation is also to promote openness and transparency for the public interest, and not to take action that is inconsistent, or not to promote interests which would harm the public interests.

\section{Social responsibility and society}

The public relations function is inseparable with society or using DRPR's code phrase; they have "important social function". Therefore, it is not surprising that in the context of PR's socially responsible behaviour, the term society takes an important place.

In the research under the term "society" were also considered different terms that are close linked to that term. According to different codes from the sample, the duty for PR practitioners includes fulfilment of social, ethical and environmental requirements; they should have a responsibility towards the broader community and not infringe rules or agreements recognized by civil society. Furthermore, they should respect current social values and the interest of society and also avoid situations in conflict with society's interests. They should also take responsibility for actions and consequences they can produce in society and to have a responsibility to an informed society and to society at large. They admit that fundamental prerequisite for practicing the profession is to operate in an open society and obligation is to disseminate the contents of the codes as a service to society. The codes reflect the awareness that PR-profession honour its role in society and is ready to accept its duties to a broader society, or in other words, has obligations to serve the interests of society.

\section{Responsibility}

The research was focused on the term of responsibility just in the case if it was linked to the concept of social responsibility behaviour. In that context, it can be found the obligation to be responsible towards: broader community, public interests, social function, public, society (informed society is also mentioned, as well as society at large). The results so far have shown that the codes of the public relations associations contain numerous concepts regarding socially responsible behaviour, although the "social responsibility" as a term is not mentioned directly. Using the content analyses, however, the research attempted to find out whether the concepts of "responsibility" and "society", or "responsibility" and "public", were mentioned within certain ethical requirements. The aim was to find out how close the codes came to the term of social responsibility at a certain ethical statement within a code. From the sample of 13 codes of ethics, there are 4 codes that contain at the certain ethical statement "responsibility" and "society" (DRPR, DIRCOM, GA and ICCO), and only 3 codes that 
mention "responsibility" and the "public "(CRPR, PRCA, and PRSA). It should be emphasized that among all analysed codes, there is no code that contains both phrases (Table 3).

Table 3

The Closest Concepts to the Term of Social Responsibility in the Codes of Ethic

\begin{tabular}{|c|c|c|c|}
\hline Responsibility to society & Codes & Responsibility to public & Codes \\
\hline $\begin{array}{l}\text { Responsibility toward their } \\
\text { important social function }\end{array}$ & DRPR & $\begin{array}{l}\text { Responsible attitude towards } \\
\text { public interest } \\
\text { Responsible also towards public } \\
\text { interest }\end{array}$ & CPRA \\
\hline $\begin{array}{l}\text { Responsibility for actions and } \\
\text { consequences they can produce } \\
\text { in society }\end{array}$ & DIRCOM & $\begin{array}{l}\text { Responsibility to deal fairly and } \\
\text { honestly above all else with the } \\
\text { public }\end{array}$ & PRCA \\
\hline $\begin{array}{l}\text { Responsibility to an informed } \\
\text { society }\end{array}$ & GA & $\begin{array}{l}\text { Conduct with the responsibility } \\
\text { to the public }\end{array}$ & PRSA \\
\hline Responsibility to society at large & $\mathrm{ICCO}$ & & \\
\hline
\end{tabular}

Source: Authors' work

\section{Loyalty}

The second research question is on the presence of loyalty in the codes. Opposite to the findings on the value of social responsibility, which is not directly mentioned in the codes, the loyalty as a principle exists among slight majority of the codes $(7 / 13)$ that are included in the sample: PRVA. CPRA, DRPR, FERPI, ASSOREL, PRSA, and GA. But as it is going to be elaborated, the principle of loyalty is not linked directly to society in any of analysed codes, whereby loyalty is a principle for relations to the clients, organizations, employers, and profession.

It is true, according to codes, that they obligate the members of associations to be loyal to the organizations' goals and policies; to the ones that members represent they need to be loyal and faithful. Furthermore, the members should behave loyally, not just towards their employers and clients but also towards the profession. In the exercise of their professional activity, they must demonstrate loyalty. But in each of analysed codes that include the principle of loyalty lexcept ASSOREL's who focuses just on the loyalty between agency and client stating that the loyalty toward agency has a primacy), in addition to ethical statements are present the words "but", "while...", "insofar..." which relativize loyalty as exclusivity for clients and others. For example, PRVA's code obligates its members to "be loyal to the organizations' goals and policies", but goes further by insisting on providing "that both are consistent with human dignity and basic human rights, the law and legislation based on them and the professional and ethical standards of the profession".

\section{Loyalty and/vs. social responsibility}

In the third research question, which seeks to find an answer to the relationship between social responsibility and loyalty, two approaches were made. Firstly, the research has taken into account the code of conduct whereby is present the principle of loyalty, aiming to see how the concept of social responsibility is treated there. The aim was to find out whether PR-professionals could be loyal and act socially responsibly at the same time. Codes of seven associations have shown that possibility: PRVA, CRPR, DRPR, FERPI, ASSOREL, PRSA, and GA.

DRPR's code illustrates that doublet by saying that "PR and communication professionals behave loyally towards their employers or clients, insofar as this does not 
violate legal requirements or ethical norms". The same code insists on their responsibility toward their important social function. Then the study narrowed down on the notion of responsibility and loyalty "to whom". The result is that there are only four codes (GA, PRSA, DRPR, CPRA) whereby members of an association are committed to being at the same time loyal to client/employer and responsible to society. For example, CPRA code says: "We are loyal to the ones we present, but at the same time we are responsible for the public interest".

\section{Discussion}

This study had opened three research questions regarding social responsibility and loyalty among codes of ethics of public relations (inter)national associations. Here are the possible answers.

Firstly, it was found that social responsibility does not exist as a term in public relations codes of ethics, although among all of them, there exist many elements of socially responsible behaviour. Secondly, the principle of loyalty is present at 7 of 13 codes, but in most cases, the loyalty was directed to relations to the client, employer or organization, and not within society. Thirdly, the analyses have shown that loyalty as an ethical principle is not staying against socially responsible behaviour; on the contrary, these two principles showed their coexistence. But in ranging these two principles, it has been shown that the loyalty to the clients, employers, and organization tends to be subordinated to socially responsible behaviour. The results of this study can be compared to some of the recent researches of ethics codes in public relations, in spite of the smaller sample. Taylor and Yang (2015) have distilled six dominant themes from codes of 41 PR-associations: professionalism, advocacy, moral standards, clients' interests, expertise, and relationships. They have also recognized "dual-responsibility for the profession to serve both clients and society/public's interests" (p. 553). The research of Kim and Ki (2014) from the sample of 45 (inter)national codes has found that the most frequently identified values were honesty, safeguarding confidences, and conflicts of interest. However, Kim and Ki (2014, p. 250) have pointed that loyalty, especially toward the clients, can be considered as "key", or universal value. The core value at both types of research mentioned above was not social responsibility.

At some further researches, it would be useful to find out why social responsibility is not the "core value" of public relations codes, although the PR-profession is inseparable from socially responsible behaviour. Public relations are among codes presented more like a "conscience of the organization" in the way Grunig presented it $(2014,20)$, by following L'Etang (2003) and Bowen (2008). He also opened a question of educational background and theoretical tools, which are also close linked to PRethics (Kolić Stanić, 2018b). Furthermore, the codes have shown that public relations are far less as blind executives of management decisions or clients' interests. This research has shown that codes give a picture of public relations as a profession that tends to be a socially responsible, as a profession in which loyalty to clients and organizations is subordinated to public and social responsibility. Thus, the codes show that contemporary public relations, at least at the normative level, approach to the two-way symmetric model and mostly promote "idealistic social role" of public relations.

\section{Conclusion}

Although this research is limited to the sample of 13 national and international codes of ethics of 18 associations from Europe and USA, the findings which place in that 
codes are taking the values of social responsibility, loyalty and their correlation can shape next conclusions.

The analysis has brought a double surprise. First, the phrase "social responsibility" does not exist at all in codes, and secondly, the value of loyalty is less represented than socially responsible behaviour, and sometimes even subordinate.

As the concept of social responsibility is (to a greater or lesser extent) present in all codes, it goes against the stereotype that public relations professionals are blindly loyal to the clients and the organization they work for. This has confirmed that public relations are increasingly becoming the "conscience of the organization," but also that they show more independence.

The normative imperatives of ethics codes of public relations show that the profession goes toward to a two-way symmetrical model, affirming the concept of "ideal communicator" who establishes a social dialogue. Although, in comparison to socially responsible behaviour, the value of loyalty is less represented (though it is more recognized as a principle) the ethical codes suggested that if a PR practitioner has to choose between loyalty to a client or organization and socially responsible behaviour, one should choose to be socially responsible. That is also supporting the claim that the profession is developing towards the two-way symmetrical model.

The principle of loyalty and social responsibility are not present as central principles in codes, which is also confirmed by previous research. But the great representation of socially responsible behaviour in the codes opens up space for it to be examined as the possible principle of social responsibility in codes.

Finally, the research of the codes has proven the possibility to be at the same time loyal to the client/organization and socially responsible. It would be interesting to explore the relationship between these two values on a larger sample that would encompass other countries and cultures, not just the West.

\section{References}

1. Barić, A. (2017), "Corporate social responsibility and stakeholders: Review of the last decade (2006-2015)", Business Systems Research, Vol. 8, No.1, pp. 133-146.

2. Benn, S., Todd, L. R., Pendleton, J. (2010), "Public relations leadership in corporate social responsibility", Journal of business ethics, Vol. 96, No. 3, pp. 403-423.

3. Bowen, S. A. (2008), "A state of neglect: Public relations as 'Corporate Conscience' or ethics counsel", Journal of Public Relations Research, Vol. 20, No. 3, pp. 271-296.

4. Bowen, S. A., Hung-Baesecke, C.-J. F., Chen, Y.-R. R. (2016), "Ethics as a precursor to organization-public relationships: Building trust before and during the OPR model", Cogent Social Sciences, Vol. 2, No. 1.

5. Boynton, L. (2002), "Professionalism and social responsibility: Foundations of public relations ethics", Annals of the international communication association, Vol. 26, No. 1, pp. 223-256,

6. Chen, F. Y., Chang, Y. H., Lin, Y. H. (2012), "Customer perceptions of airline social responsibility and its effect on loyalty", Journal of Air Transport Management, Vol. 20, pp. 49-51.

7. Clark, C. E. (2000), "Differences between public relations and corporate social responsibility: An analysis", Public Relations Review, Vol. 26, No. 3, pp. 363-380.

8. Daymon, C., Holloway, I. (2010), Qualitative research methods in public relations and marketing communications, Routledge, London.

9. Du, S., Bhattacharya, C. B., Sen, S. (2010), "Maximizing business returns to corporate social responsibility (CSR): The role of CSR communication", International journal of management reviews, Vol. 12, No. 1, pp. 8-19.

10. Farmer, Y. (2018), "Ethical Decision Making and Reputation Management in Public Relations", Journal of Media Ethics, Vol. 33, No. 1, pp. 2-13.

11. Fitzpatrick, K., Gauthier, C. (2001), "Toward a professional responsibility theory of public relations ethics", Journal of Mass Media Ethics, Vol. 16, No. 2-3, pp. 193-212. 
12. Grunig, J. E. (2006), "Furnishing the edifice: Ongoing research on public relations as a strategic management function", Journal of Public relations research, Vol. 18, No. 2, pp. 151-176.

13. Grunig, J. E. (2014), "Ethics problems and theories in public relations", Communiquer, Vol. 11, pp. 1-14.

14. Grunig, J. E., White, J., (1992). "The effect of worldview on public relations theory and practice," in Grunig, J. E. (Ed.), Excellence in Public Relations and Communication Management, Hillsdale, NJ, Lawrence Erlbaum Associates, pp. 51-54.

15. Jackson, D., Moloney, K. (2019), "'Uneasy lies the head that wears a crown'. A qualitative study of ethical PR practice in the United Kingdom", Public Relations Inquiry, Vol. 8, No.1, pp. 87-101.

16. Jones, K., Bartlett, J. L. (2009), "The strategic value of corporate social responsibility: a relationship management framework for public relations practice" PRism, Vol. 6, No. 1.

17. Kim, S. Y., Park, H. (2011), "Corporate social responsibility as an organizational attractiveness for prospective public relations practitioners", Journal of business ethics, Vol. 103, No. 4, pp. 639-653.

18. Kim, S. Y., Reber, B. H. (2008), "Public relations' place in corporate social responsibility: Practitioners define their role", Public Relations Review, Vol. 34, No. 4, pp. 337-342.

19. Kim, S.-Y. Ki, E.-J. (2014), "An Exploratory Study of Ethics Codes of Professional Public Relations Associations: Proposing Modified Universal Codes of Ethics in Public Relations", Journal of Mass Media Ethics, Vol. 29, No. 4, pp. 238-257.

20. Kim, S.-Y., Reber, B. H. (2009), "How public relations professionalism influences corporate social responsibility: A survey of practitioners", Journalism \& Mass Communication Quarterly, Vol. 86, No. 1, pp. 157-174.

21. Kolić Stanić, M. (2018a) "Criteri fondamentali delle relazioni pubbliche nei codici di etica. Un confronto con i criteri etici del giornalismo secondo Luka Brajnovic" ("Fundamental criteria of public relations in codes of ethics. A comparison with the ethical criteria of journalism according to Luka Brajnović"), Dissertation, Rome, Pontifical University of the Holy Cross, pp. 186-194.

22. Kolić Stanić, M. (2018b), "Education as the Essential Part of Public Relations Ethics Codes", in the Proceedings of the 4th ENTerprise REsearch InNOVAtion Conference, Udruga za promicanje inovacija i istraživanja u ekonomiji "IRENET", Zagreb, Croatia, pp. 98-104.

23. Kolić Stanić, M. (2018c), "Ethics as the Strategy for Public Relations Associations", in the Proceedings of the 4th ENTerprise REsearch InNOVAtion Conference, Udruga za promicanje inovacija i istraživanja u ekonomiji "IRENET", Zagreb, Croatia, pp. 120-126.

24. Kolić Stanić, M. (2019), "Transparency in Public Relations: Evidence from Associations' Ethics Codes", Interdisciplinary Description of Complex Systems, Vol. 17, No. 2-B, pp. 417-429.

25. Krippendorff, K. (1980), Content Analysis: An Introduction to its Methodology, Sage Publications, Newbury Park.

26. L'Etang, J. (2003), "The myth of the 'ethical guardian': An examination of its origins, potency, and illusions", Journal of Communication Management, Vol. 8, No. 1, pp. 53-67.

27. May, S. (2008), "Reconsidering strategic corporate social responsibility: Public relations and ethical engagement of employees in a global economy", in Zerfass A., van Ruler B., Sriramesh K. (Eds), Public Relations Research, VS Verlag für Sozialwissenschaften, Wiesbaden, pp. 365-383.

28. Pejić Bach, M., Omazić, M. A., Zoroja, J. (2015), "Transparency as a Precondition of Systemic Behavior: the Case of European Retailing Banks Regarding Social Responsibility Communication", Systems Research and Behavioral Science, Vol. 32, No. 2, pp. 256-264.

29. Pompper, D. (2015), Corporate social responsibility, sustainability and public relations: Negotiating multiple complex challenges, Routledge, London-New York,

30. Preciado-Hoyos, A. (2013), "The role of public relations in corporate social responsibility programs in the Colombian electricity sector", Public Relations Review Vol. 39, No. 5, pp. 591-593.

31. Stoker, K. (2005), "Loyalty in Public Relations: When Does It Cross the Line Between Virtue and Vice?", Journal of Mass Media Ethics, Vol. 20, No. 4, pp. 269-287. 
32. Taylor, M., Yang, A. (2015), "Have Global Ethical Values Emerged in the Public Relations Industry? Evidence from National and International Professional Public Relations Associations", Journal of Business Ethics, Vol. 130, No. 3, pp. 543-555.

33. Vlachos, P. A., Tsamakos, A., Vrechopoulos, A. P., Avramidis, P. K. (2009). "Corporate social responsibility: attributions, loyalty, and the mediating role of trust", Journal of the Academy of Marketing Science, Vol. 37, No. 2, pp. 170-180.

34. Wright, D. K. (1979), "Professionalism and social responsibility in public relations", Public Relations Review, Vol 5, No. 3, pp. 20-33.

35. Yang, A., Taylor, M. (2013), "The relationship between the professionalization of public relations, societal social capital and democracy: Evidence from a cross-national study", Public Relations Review, Vol. 39, No. 4, pp. 257-270.

36. Yang, A., Taylor, M., J. Saffer, A. J. (2016), "Ethical convergence, divergence or communitas? An examination of public relations and journalism codes of ethics", Public Relations Review Vol. 42, No. 1, pp.146-160.

\section{About the authors}

Matilda Kolić Stanić graduate at the Pontifical University of the Holy Cross in Rome, where she got her Ph.D. with the topic "Fundamental criteria of public relations in codes of ethics. A comparison with the ethical criteria of journalism according to Luka Brajnović". Her research interests are public relations, media relations, ethics, and communication. She participated in the projects "Family and Media" and "Science communication: the role of scientific community and curriculum development." as a research assistant at the University Department of Croatian Studies, University of Zagreb. The author can be contacted at kolicstanicmatilda@gmail.com.

Anton Florijan Barisic is a senior lecturer at the University for applied sciences VERN, Zagreb. He obtained his Ph.D. degree at Fakulteta za komercialne in poslovne vede, Celje, Slovenia. Within Erasmus + programme he holds lectures at the University Maya, Porto, Portugal, Fakulteta za komercialne in poslovne vede, Celje, Slovenia and Helena Chodkowska University of Management and Law, Warsaw, Poland. As an author or co-author, he wrote about 50 scientific and professional papers, case studies and articles. As a project manager or key expert, he participated in the realization of a series of projects funded by the EU. He is also working as an expert for international institutions such as the EU Commission, EBRD, WB, and UNDP. The author can be contacted at afbarisic@chronos.hr. 


\section{Appendix}

1. Asociación de Directivos de Comunicación (Dircom), "Código ético", available at: http://www.dircom.org/sobre-dircom/codigo-etico (21 March 2017).

2. Asociación de Empresas Consultoras en Relaciones Públicas y Comunicación (ADECEC), "Código ético", available at: http://www.adecec.com/quienes_somos/codigo_etico.php (22 March 2017).

3. Associazione imprese di comunicazione e relazioni pubbliche (Assorel), "Principi professionali e codici di comportamento delle Relazioni Pubbliche in Italia", available at: https://www.assorel.it/relazioni-pubbliche/assorel-rp-0002156.html (20 March 2017).

4. Chartered Institute of Public Relations (CIPR), "Chartered Institute of Public Relations Code of Conduct", available at: https://www.cipr.co.uk/sites/default/files/Appendix\%20A\%20\%20Code\%20of\%20Conduct\%20-\%20Updated\%20 June\%202012.pdf (19 September 2017).

5. Deutscher Rat für Public Relations (DRPR), "The German Communication Code", available at:

http://drpr-online.de/wp-content/uploads/2015/11/German_Communication_Code.pdf (3 March 2017).

6. Federazione Relazioni Pubbliche Italiana (FERPI), "Codice di Comportamento Professionale della FERPI", available at:

http://www.ferpi.it/associazione/statuto-regolamento-e-codici/codici/codice-dicomportamento-professionale-della-ferpi/ (19 September 2017).

7. Global Alliance for Public Relations and Communication Management (GA), "Global Protocol on Ethics in Public Relations", available at: https://staticl.squarespace.com/static/561d0274e4b0601b7c814ca9/t/56c202bcc2ea51 0748cb2171/1455555260837/GA_Global_Ethics_Protocol.pdf (19 September 2017).

8. Hrvatska udruga za odnose s javnošću (HUOJ, eng. CPRA), "Eticki kodeks Hrvatske udruge za odnose s javnošću", available at:

http://www.huoj.hr/files/File/Eticki_kodeks_HUOJ_final.pdf (19 September 2017).

9. International Communications Consultancy Organization (ICCO), "The ICCO Stockholm Charter", available at:

https://iccopr.com/wp-content/uploads/2015/01/StockholmCharter.pdf (1 1 July 2017).

10. Public Relations Council (PR Council), "The PR Council Code of Ethics and Principles", available at: http://prcouncil.net/join/the-pr-council-code-of-ethics-and-principles/

(19 September 2017). 